\title{
Effectiveness of geocell wall, geogrid and micropile anchors for mitigation of unstable slopes
}

\author{
Jain Sanjaya Kumar ${ }^{1 *}$ (D), Mohammed Saleh Nusari', Dangol Purushotam², Acharya Indra Prasad ${ }^{3}$ and \\ Shrestha Rajyaswori ${ }^{4}$
}

\begin{abstract}
Slope failure mitigation practices are well developed in recent years. Recently, geosynthetic, geocell, and geogrid combined with micropiles are being used extensively in various slope stabilization works. But integrated approaches are still lacking. In this study, a method of slope stabilization is proposed by integrated use of micropile, geocell and geogrid from an engineering and economical point of view. The study was done on slope failure located at Chandragiri Hill, south west of Kathmandu, Nepal. Geotechnical problems of the site, the design of geocell foundation, micropile and geogrid are done on the based on numerical analysis using Phase-2 software with field data. The results of analytical studies revealed that, the use of a combination of geocell, micropile and geogrid is beneficial in increasing slope stability. As per numerical analysis, in the slope failure site, geocell gravity walls each of $3.8 \mathrm{~m}$, is constructed in different step. Beneath the geocell wall, different layers of geogrid were placed filled with granular materials. The geocell wall is connected with micropile from inside. The micropile works as an anchorage and support for geocell wall, which increases the stability of a failed slope.
\end{abstract}

Keywords: Slope stability, Geocell, Geogrid, Reinforcement, Micro pile, Granular material

\section{Introduction}

The modifications in the geomorphic, hydrological and geological conditions of the area that is mainly facilitated by geodynamic processes, vegetation, and land use practices, human activities, seismicity, rainfall are the factors that trigger slope instability. Dealing with the problem of instability of slopes has always been interesting, important and challenging in the field of geotechnical engineering. Slope failures and instability are encountered in various stages and sectors of engineering such as during cutting, construction of hill roads, railway lines, reservoirs and damns among others (Soeters and Van Westen 1996). There are various methods for slope failure mitigation. In recent years, geosynthetic, geocell, and geogrid combined with micropiles are being used extensively in various slope stabilization works. A geosynthetic can be

\footnotetext{
* Correspondence: gsgroup.sanju@gmail.com

1 Lincoln University College, Kota Bharu, Malaysia

Full list of author information is available at the end of the article
}

defined as a planar product manufactured from polymer used with soil, rock, earth, or other geotechnical engineering related material as an integral part of a manmade project, structure or system. The use of geocell is the most recent advancement in soil reinforcement where the materials are confined in three-dimensional pockets (Dash et al. 2001). Micropiles are widely used to stabilize slopes especially for slopes located in steep, hilly, or mountainous areas; as they are simple, fast, economical and environmentally friendly. Micropiles are defined as a small diameter (generally less than $300 \mathrm{~mm}$ ) non displacement pile, generally reinforced, which are driven into the soil and grouted (Sun et al. 2014). Many researchers have found that the use of piles is one of the effective methods in the stabilization of slopes. Lee et al. (1995) and Li et al. (2012) studied stabilization slopes using a simple approach by means of row of piles driven into the slope. Ausilio et al. (2001) has studied stability of slopes that are reinforced with piles using the 
kinematic approach of limit analysis. Geocell is threedimensional cell made from high-density polyethylene (HDPE) or polyethylene (PE) strips ultrasonically welded along the width. Geocells are better alternatives to conventional slope stability measures like use of concrete panels. Also geocell perform better than the concrete panels in cold weather conditions (Dash et al. 2003).

The main properties of geogrid consist of uniformity, stability, light, anti-corrosive, anti-aging, high tensile strength and flexibility. Geogrids reduces the joggling of filling materials, reduce the inhomogeneous settlement of soil to the largest possible degree and improve stability. These are obvious advantages of using geogrid as reinforcement in retaining walls. With the rising problem of global warming and environmental concerns, geosynthetic materials as a measure for reinforcing soil and preventing soil erosion caused by runoff water have gained a worldwide acceptability (Yadav et al. 2014). Wu and Austin (1992) reported the use of geocell for slope stability and for erosion control, as well as the walls of geocell controlled the downward movement of materials as they are confined.

Dash et al. (2003), Krishnaswamy et al. (2000), Madhavi Latha et al. (2006), Mehrjardi et al. (2012), Sireesh et al. (2009), Tafreshi and Dawson (2010) and (Tafreshi and Dawson 2012); Yang et al. (2012), Zhang et al. (2010), Zhou and Wen (2008) studied beneficial effects of geocell on increasing the load bearing capacity of soil as well as decreasing the footing displacement. (Chen and Chiu 2008) confirmed that geocell in an increased length perform similar to geogrid layers and provide reinforcement to the soil. Ling et al. (2009) showed that geocell can perform well in gravity walls as well as reinforcement walls. Cancelli et al. (1993) tested that in steep slopes and areas of heavy surface runoff, where vegetation is not effective in controlling soil erosion. Geocell can be used as it has good tensile strength and confines infill material as well as reduce the velocity of surface runoff.

Palmerton (1984) and Pearlman and Wolosick (1992), suggested that in case of soft or weak soil, to transfer the axial and lateral load to more stable strata, micropiles are the perfect solution. Meantime, Pokharel et al. (2010) suggested that the three-dimensional geocell provided lateral confinement, base acts as a mattress to restrain the soil from moving upward outside the loading area.

This research has attempted to validate the least popular but economical solution for mitigation and control of critical slopes. For this purpose, geocell and micropiles along with the combination of geogrid reinforced soil were used. In many cases, micropile, geocell and geogrid are suitable options to mitigate slope instability issues and this research work attempted to evaluate the effectiveness of geocell, geogrid and micropiles against retaining walls in critical slope and mitigation of unstable slopes. Futhermore, the site at Chandragiri hills of

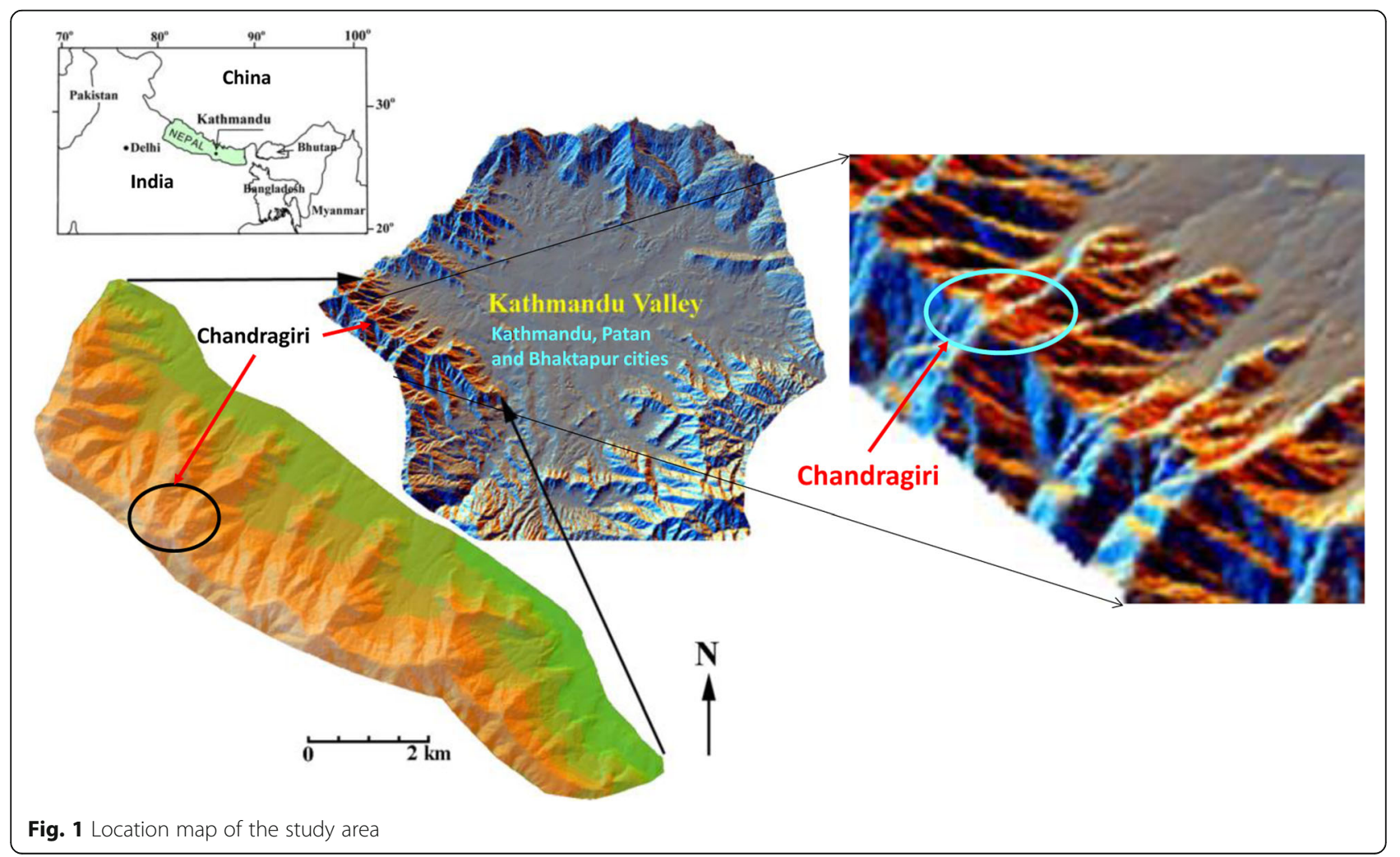


Kathmandu Valley, Nepal has been selected for the research and design and implementation of all necessary slope stabilization works.

\section{Study area}

The study area lies on South-West of Kathmandu Valley at Chandragiri Municipality, Kathmandu district of Bagmati Province, Nepal (Fig. 1). Physiographically, the study area belongs to the part of the Mahabharat Range of Central Nepal representing a strongly dissected range of topographic variations with moderate to a very steep slope, ridge, spur, saddle and valley (Dahal et al. 2008).

Geologically, it lies in the Lesser Himalaya Zone of central Nepal (Stöcklin and Bhattarai 1977). The research area lies within longitude $85^{\circ} 12^{\prime} 30.98^{\prime \prime} \mathrm{E}$ to $85^{\circ} 12^{\prime} 36.99^{\prime \prime} \mathrm{E}$ and latitude $27^{\circ} 39^{\prime} 57.12^{\prime \prime} \mathrm{N}$ to $27^{\circ} 39^{\prime} 59.54^{\prime \prime} \mathrm{N}$ and elevation of $2300 \mathrm{~m}-2450 \mathrm{~m}$. The research was mainly focused on the landslides that occurred on the northern slope (Fig. 2). There is a resort that lies near the landslide area and has a famous panoramic view of the Himalayas as well as the Kathmandu city.

\section{Regional geological setting}

Geologically it lies in the Lesser Himalaya Zone of central Nepal south of great Himalayan Range (Dahal et al. 2008; Hagen 1969; Stöcklin and Bhattarai 1977). Kathmandu valley is an intermountain basin with valley floor surrounded by four mountain ranges from Shivapuri, Phulchoki, Nagarjun and Chandragiri located in North, South-East, North-West and South- West respectively. The geology of the Kathmandu Valley and its surroundings can be put into two groups, unconsolidated-slightly consolidated sediment deposits (Quaternary deposits) and hard rocks of Precambrian to Devonian (Stöcklin and Bhattarai 1977). The central part of the valley has lacustrine and fluvial deposits containing peat, clay, carbonaceous clay, sand, gravel, and boulders which overlie uncomfortably on the rocks of the Phulchauki and Bhimphedi groups (Fig. 2).

Hard rock geology around the Kathmandu Basin is comprised of various sedimentary, meta-sedimentary and metamorphic rocks. The rock formation surrounding the basin belongs to the Phulchauki Group of the Kathmandu Complex. The Phulchauki Group is divisible into five formations: Tistung Formation, Sopyang Formation, Chandragiri Limestone, Chitlang Formation, and Devonian Limestone of Phulchauki. Sheopuri Gniess (Fig. 2) is present on the northern hills (Stöcklin and Bhattarai 1977).

The study area lies in the vicinity of the contact of the Chandragiri Limestone and Chitlang Formation on Chandragiri mountain range. Residual/colluvial deposit has covered the underlying bedrock of Chandragiri

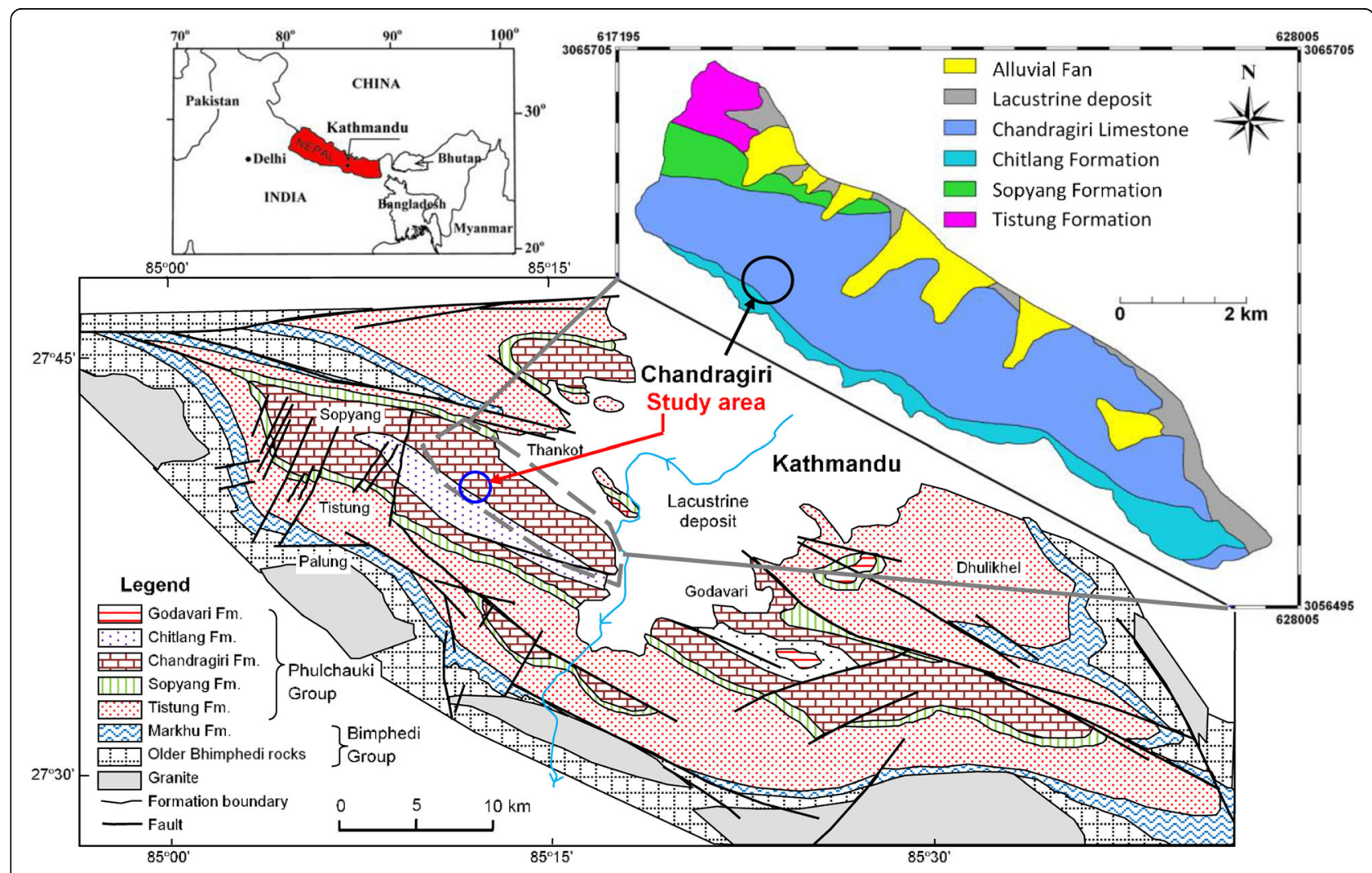

Fig. 2 Study area on regional geological map of Kathmandu basin (modified after Stöcklin and Bhattarai 1977 and Dahal et al. 2009) 
Limestone and Chitlang Formation (Fig. 2). The Chandragiri Limestone of Middle Cambrian age consists of grey, thin to thick bedded argillaceous, laminated limestone with minoramount of white, ortho-quartzite, light grey with orange weathered argillaceous phyllite and greyish, micaceous metasandstone. The upper part of the succession comprises partings of dark grey to light grey phyllite subordinated with white quartzite (about $150 \mathrm{~m}$ ) band and greyish leachate on limestone. The Elephant-skin type weathering on limestone is observed in some parts. The Chitlang Formation of Silurian age consists mainly of white quartzite, some beds of argillaceous limestone, dark bluish grey, violet shale, slate and dolomitic limestone. The lower part of this unit consists of violet, shale and slate, white, muddy quartzite, grey, fine-to coarse grained meta sandstone, thick-to massive, fine-to medium-grained limestone and phyllite in some parts. Similarly, the upper-part of succession comprises intercalation between yellowish grey shale and dark grey limestone minorly of dolomite with precipitated calcite in which wave marks are observed.

The study was focused on the landslide mass consisting of fine, reddish brown, moist, sandy silt to silt with pebbles, cobbles as overburden deposit and dark grey, weathered and fractured slates as exposed bedrock only a few locations.

\section{Site and soil characteristic}

The site has a four storey building of the Chandragiri Hills Resort with an isolated foundation (Fig. 3). There is a topographic map shown in Fig. 4. There was a stone masonry wall constructed around periphery of the building without proper drainage system for surface runoff. The downward slope angle of slope is more than $42^{\circ}$, width $30 \mathrm{~m}$ and length $20 \mathrm{~m}$. The pore water pressure on the slope during rainy season cannot be released through the retaining structure.

The site is located on a moderately steep slope that is a landslide prone zone. The down slope is bare and runoff and rainfall can infiltrate easily due to the fracture of rock underlain by a thin veneer of red soil. The soil is unstable both in rainy as well as dry season due to its silty nature. The slope is north facing. As a result the moisture remains on the slope for a long time after rainfall and snowfall in winter. The area was well vegetated before the resort construction (Dahal et al. 2009) but the vegetation was removed for construction purpose in the surrounding area that resulted erosion and failure problems. The slope consists of red silt soil from $1 \mathrm{~m}-1.5 \mathrm{~m}$ depth with rock fragments and the yellowish fractured rock is present from $1.5 \mathrm{~m}$ to $6 \mathrm{~m}$. The weathered slate and calcareous rocks are mainly present after $6 \mathrm{~m}$ in the site. The soil has specific gravity 2.69 and friction angle

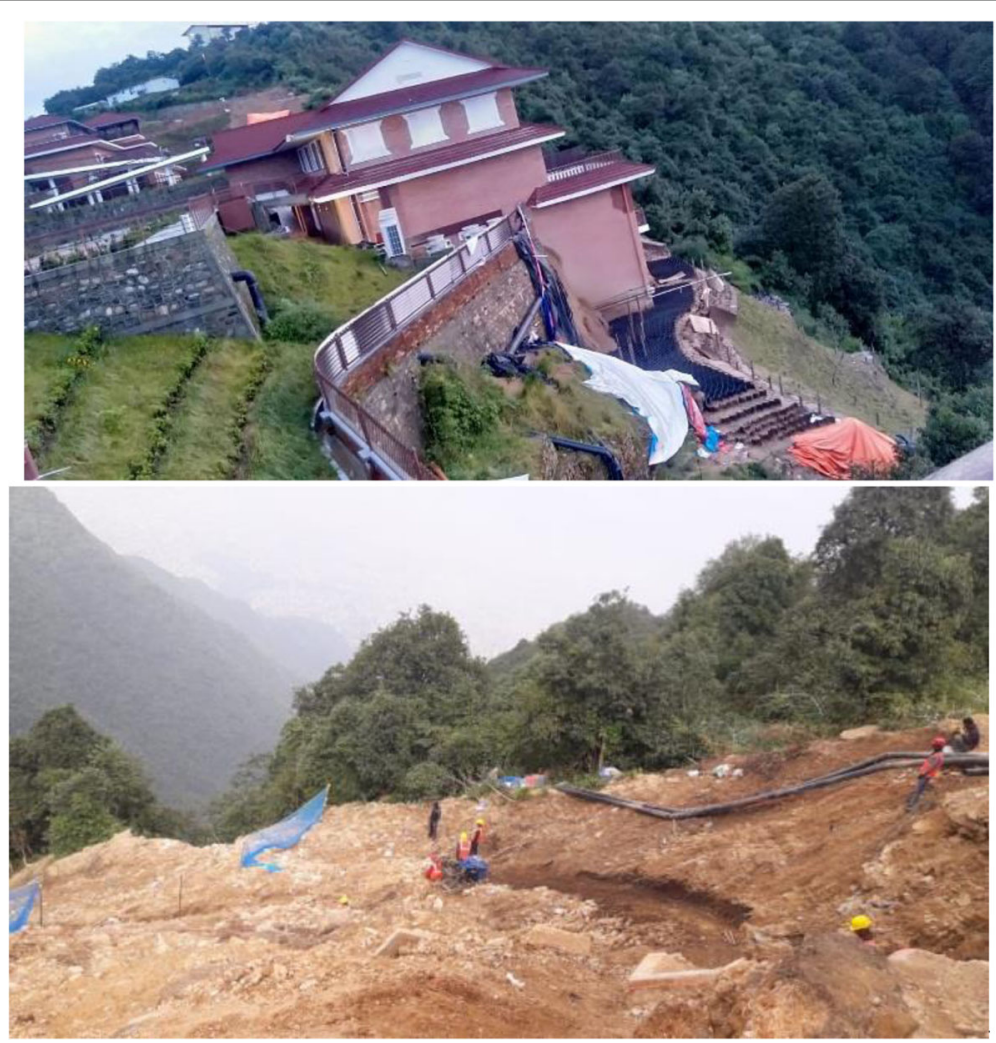

Fig. 3 Four stories building and landslide in the slope just below the building 


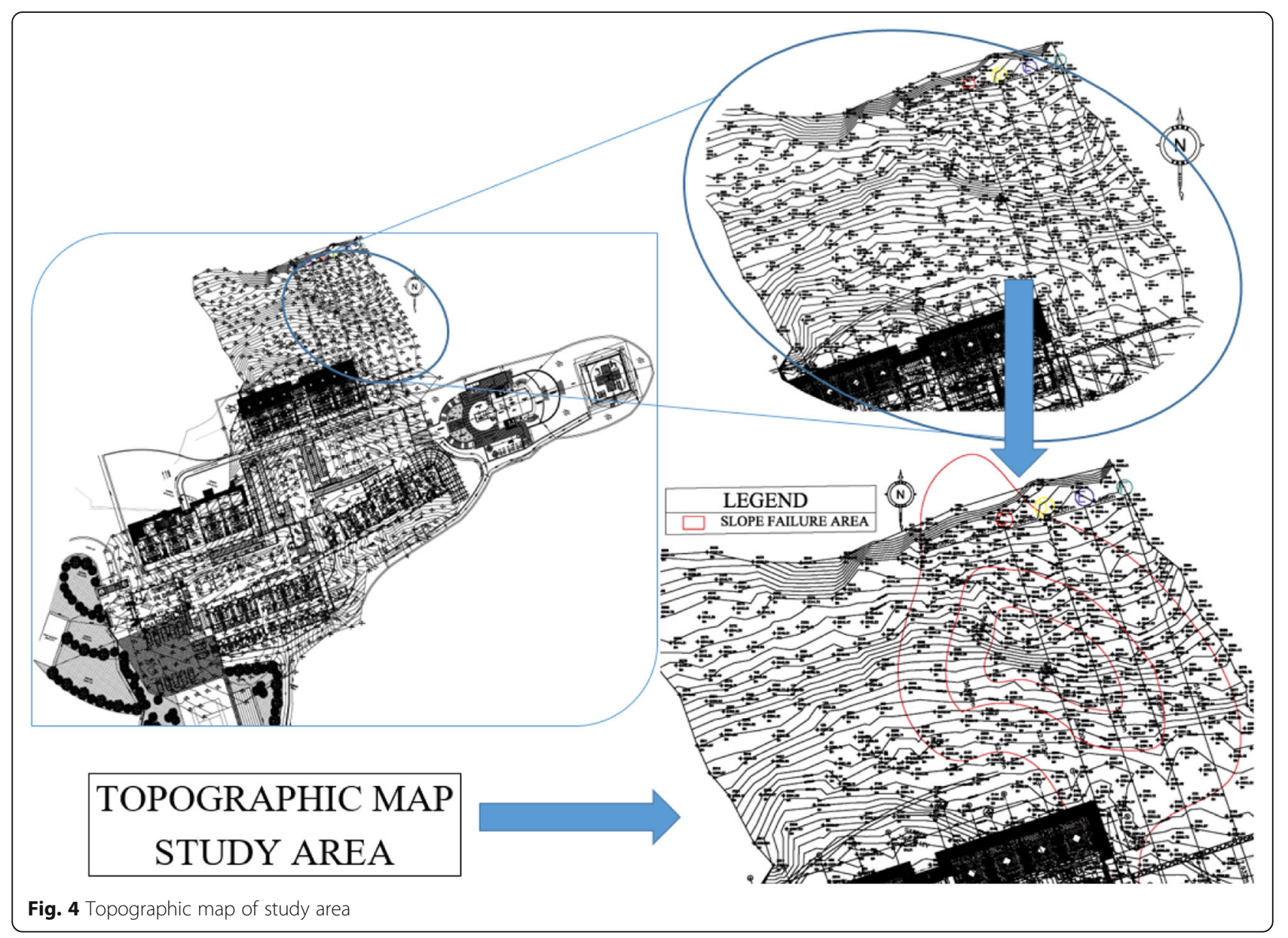

( $\phi) 36^{\circ}$ and the moisture content of the soil varied from $9 \%$ to $16 \%$ with a bulk density of $2.07 \mathrm{~g} / \mathrm{cm}^{3}$.

\section{Materials and methods}

In this research, effectiveness of geocells and micropiles along with the combination of geogrid reinforced soil was explored for the slope stabilization. At first, numerical analysis was performed for the project site using geocell, geogrid and micropiles. Then the field application of micropiles, geogrid and geocell were done to mitigate the slope instability as per the numerical result. Following - materials and methods are used in the research process.

\section{Geocell}

Geocell is a honeycomb three-dimensional cell structure (Fig. 5) that confines the filled compacted materials, decreases the lateral movement of soil particles and distributes the applied loads to a wider area. Geocell is generally used in the construction of canals, embankments, retaining walls, railways and roads, slope stability (Bathurst and Jarrett 1988; Dash et al. 2003). Geocell is a blanket of three dimensional cell structures applied to a slope surface and wall to greatly improve resistance to erosive forces such as rainwater run-off on steep or unstable slopes, or slopes exposed to severe hydraulic or mechanical stresses (Wu and Austin 1992).

\section{Filling materials}

For filling, the specific gravity of filling material was 2.66. Likewise, liquid limit and plastic limit of the clay were $40 \%$ and $19 \%$, respectively. The maximum dry density, optimum moisture content, Standard Proctor test were $18.2 \mathrm{kN} / \mathrm{m}^{3}$ and $13.2 \%$, respectively. The effective particle size $\left(D_{10}\right)$ was $0.26 \mathrm{~mm}$. The angle of internal friction was 40 degree. Poorly graded sand was used and it was SP according to unified soil classification system (USCS). Average size of the gravel was $12 \mathrm{~mm}$ according to unified soil classification system, graded gravel (GP).

Normally, select fill materials are more expensive than lower quality materials. The gradation requirements for granular reinforced fill, gradation 4 in $-100 \%$ passing, $40 \mathrm{~mm}-60 \%$ passing, $200 \mathrm{~mm}-50 \%$ passing and plasticity index $\leq 20$ (AASHTO T-27, T90).

For this study, the filling material used was GM (silty gravel) as per ISC and USC system. 


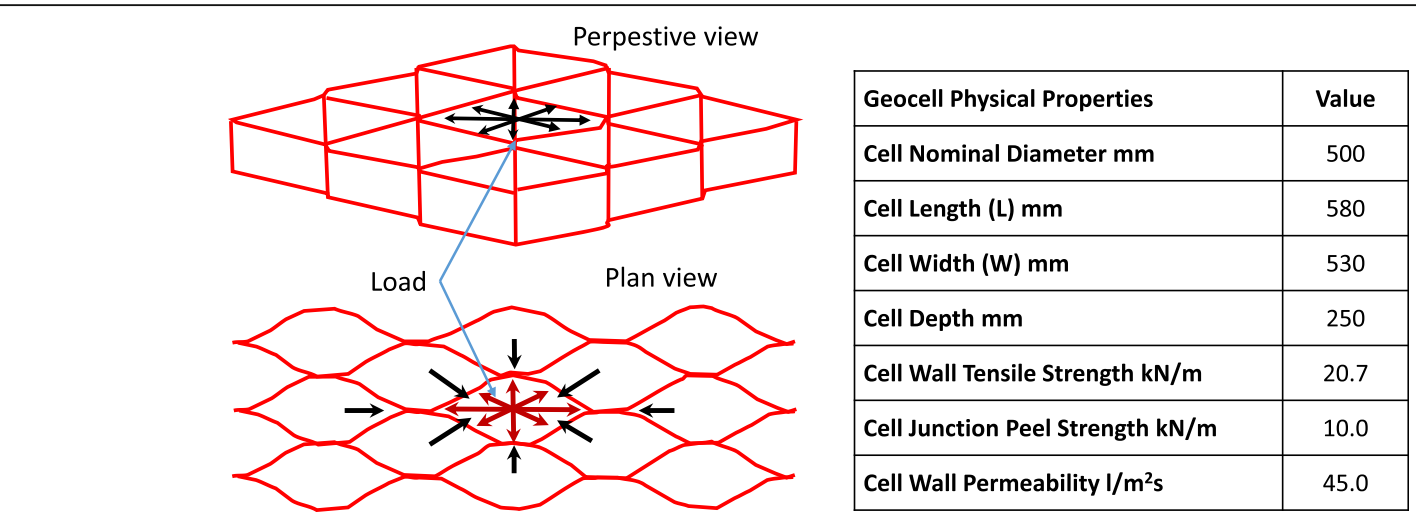

Fig. 5 Schematic drawing of typical geocell and physical, mechanical and hydraulic parameters

\section{Geogrid}

Geogrids are manufactured by polymers like PET (as per ASTM D2455, ASTM 4603 as per ASTM D1248), they have apertures in various sizes between individual ribs in the transverse and longitudinal directions. PET and HDPE Geogrids have minimum UV resistance as per ASTM D4355. Geogrids are (a) either stretched in one, two or three directions for improved physical properties, (b) made on woven/knitted machinery by standard textile manufacturing methods.

In this study, biaxial geogrid is used with the characteristics shown in (Fig. 6).

\section{Micropile}

The micropile was used in an unstable slope with geocell. The micropile has a small diameter and it is easy to transport and install even by semi-skilled person. Micropile bears the axial loads and lateral load therefor it can be constructed in any type of soil/rock/sand conditions. Micropile depends on location, slope, cross section, length, group spacing and concrete cap beam of micropile (Lizzi 1982). In this case study, micro piles are castin-situ with $101 \mathrm{~mm}$ MS medium pipe drilled hole of the specified size $150 \mathrm{~mm}$ (diameter). The cement grouting was done in the drilled hole under a pressure with perforated pipe to spread the slurry into the surrounding soil. After completing grouting process, the reinforcement is lowered into the hole.

\section{Methods of analysis}

In this research, Phase 2 (2002), a Rocscience FE program was used to simulate and analyze a complex multistage model (Fig. 7) for slope stability analysis. Material properties of model is taken as; Elastic modulus 15,000 $\mathrm{kPa}$, Poisson's ratio 0.3 , tensile strength $5 \mathrm{kPa}$, friction angle $30^{\circ}$, cohesion $5 \mathrm{kPa}$ shown in Table 1 . For vertical boundary, $\mathrm{u}_{\mathrm{x}}=0$ and $\mathrm{u}_{\mathrm{y}}$ is free and for horizontal boundary; $u x=u y=0$. Mohr Coulomb failure criterion is used to simulate the model. The shear strength reduction (SSR) technique of Finite Element (FE) and the simplified Bishop method was used to analyze the slope stability problem to gain insight into the soil mass behavior, progressive failures and explicit modelling of discontinuities. In both methods, at first the existing failed slope conditions were analyzed and checked for their stability $(\mathrm{FoS}<1$ or $\mathrm{FoS}>1)$. When $\mathrm{FoS}<1$, to improve the slope

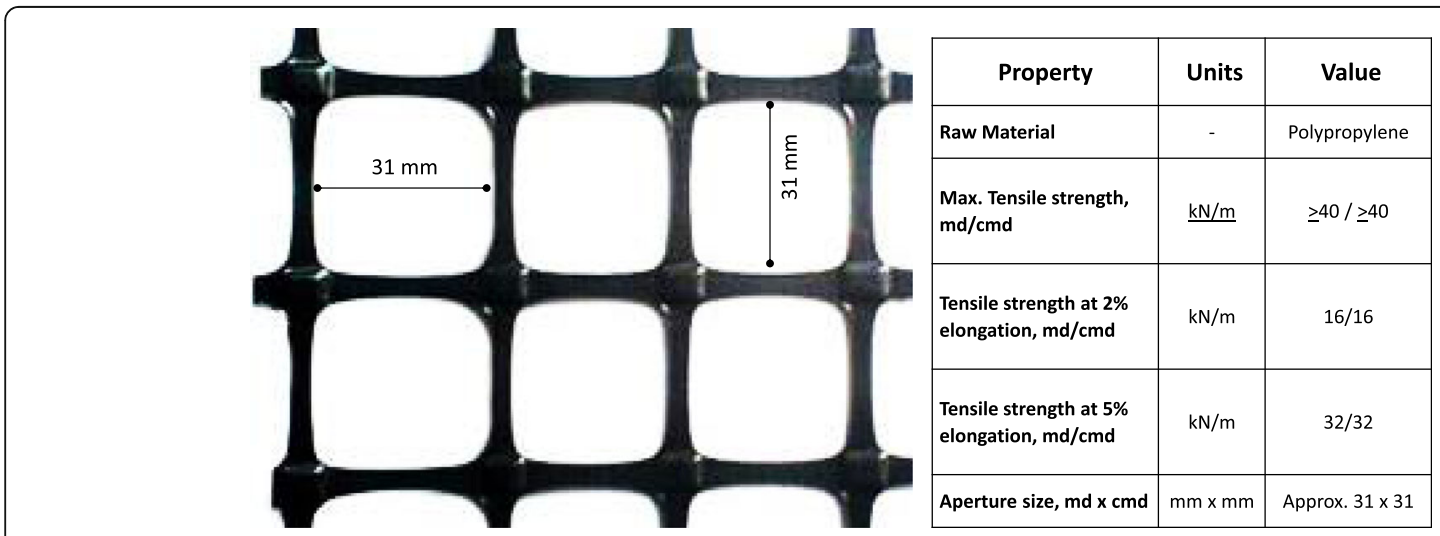

Fig. 6 Grid used in the field construction and properties of geogrid 


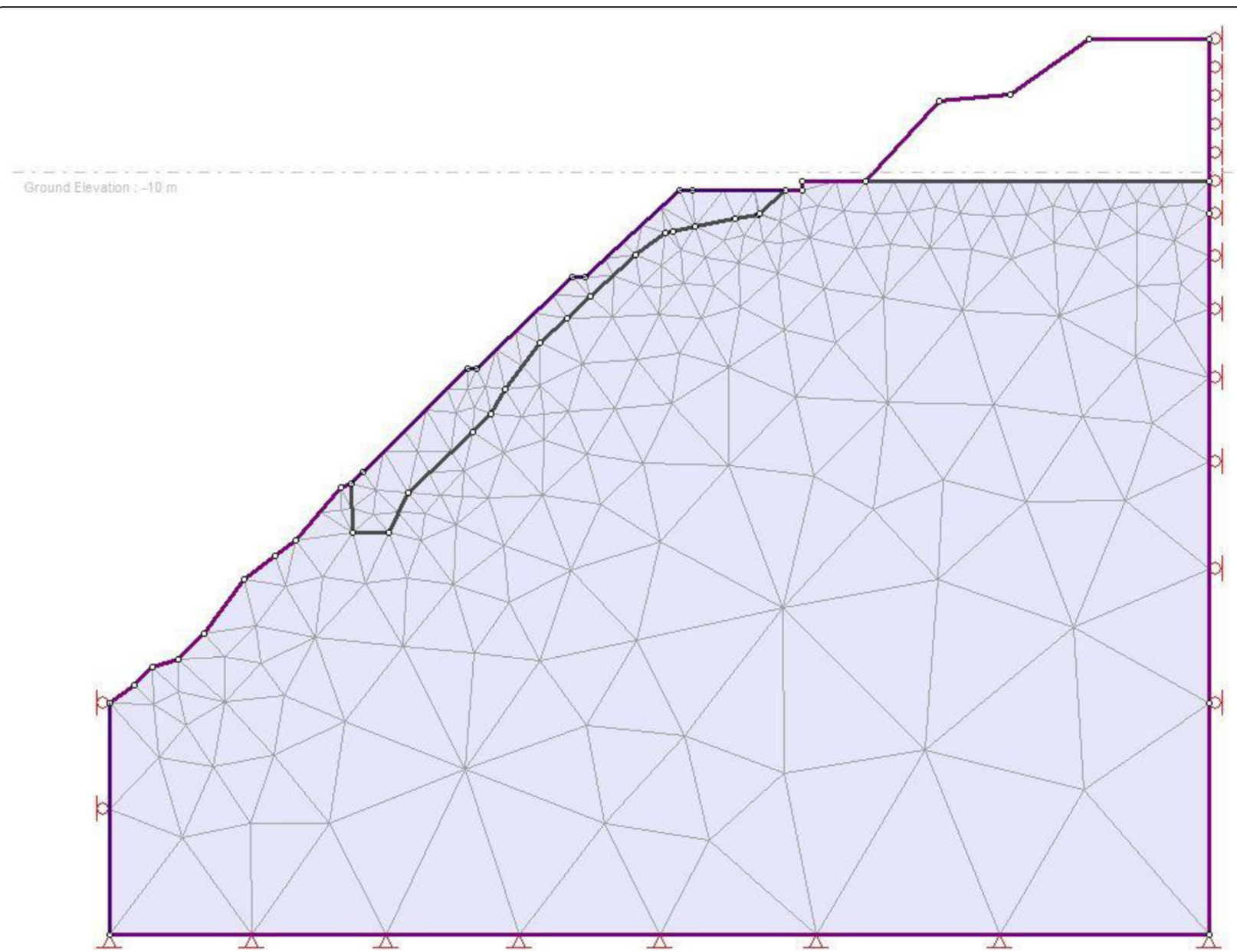

Fig. 7 Schematic diagram of slope for FEM based simulation

stability and increase the factor of safety the existing soil was reinforced with the use of a combinations of micropile, geocell and geogrid.

The shear strength reduction (SSR) technique of Finite Element (FE) slope stability analysis is a simple approach that involves a systematic search for a stress reduction factor (SRF) or factor of safety value that brings a slope to the very limit failure. The SSR technique assumes Mohr Coulomb strength for slope materials. The Mohr Coulomb strength envelope is the most widely applied failure criterion in geotechnical engineering. A unique

Table 1 Modeling parameters

\begin{tabular}{ll}
\hline Modeling parameters & \\
\hline Elastic Modulus & $15,000 \mathrm{kPa}$ \\
Poisson's ratio & 0.3 \\
Tensile strength & $5 \mathrm{kPa}$ \\
Friction angle & $30^{\circ}$ \\
Cohesion & $5 \mathrm{kPa}$ \\
Constitutive model & Mohr coulomb failure criterion \\
\hline
\end{tabular}

feature of this linear failure model is the fact that it can be simply and explicitly expressed in both principal $\left(\sigma_{1^{-}}\right.$ $\left.\sigma_{3}\right)$ stress space and shear-normal $\left(\tau-\sigma_{n}\right)$ stress space. The simplicity, explicit representation in both principal and shear-normal stress space, an adequate description of strength behavior for a wide range of materials, and easy to obtain parameters of the Mohr-Coulomb criterion account for its popularity. For Mohr-Coulomb material the factored or reduced shear strength can be determined from the equation

$$
\frac{\mathrm{\tau}}{\mathrm{F}}=\frac{\mathrm{c}^{\prime}}{\mathrm{F}}+\frac{\tan \phi^{\prime}}{\mathrm{F}}
$$

This equation can be re-written as

$$
\frac{\mathrm{T}}{\mathrm{F}}=\mathrm{c}^{*}+\tan \phi^{*}
$$

Where, $\mathrm{F}$ = factor of safety; c' = effective parameter of cohesion; $\tau^{\prime}$ = effective shear strength; $\phi^{\prime}=$ effective angle of internal friction 


$$
\mathrm{c}^{*}=\frac{\mathrm{c}^{\prime}}{\mathrm{F}} \text { and } \phi^{*}=\arctan \frac{\tan \phi^{\prime}}{\mathrm{F} .}
$$

The steps for systematically searching the critical factor of safety value $\mathrm{F}$ that brings a previously stable slope $(F \geq 1)$ to the verge of failure are as follows:

Step 1: Develop an FE model of a slope, using the appropriate materials deformation and strength properties. Compute the model and record the maximum total deformation.

Step 2: Increase the value of F (or SRF) and calculate factored Mohr Coulomb material parameters as described above. Enter the new strength properties into the slope model and recomputed. Record the maximum total deformation.

Step 3: Repeat step 2, using systematic increments of F, until the FE model does not converge to a solution, i.e. Continue to reduce material strength until the slope fails. The critical F value just beyond which failure occurs will be the slope factor of safety.

For a slope with a factor of safety less than 1, the procedure is the same except fractional $\mathrm{F}$ values will be systematically decremented (translating into increments in the factored strength parameters) until the slope becomes stable.

The principal advantage of the SSR technique is its use of factored strength parameters as input into models,

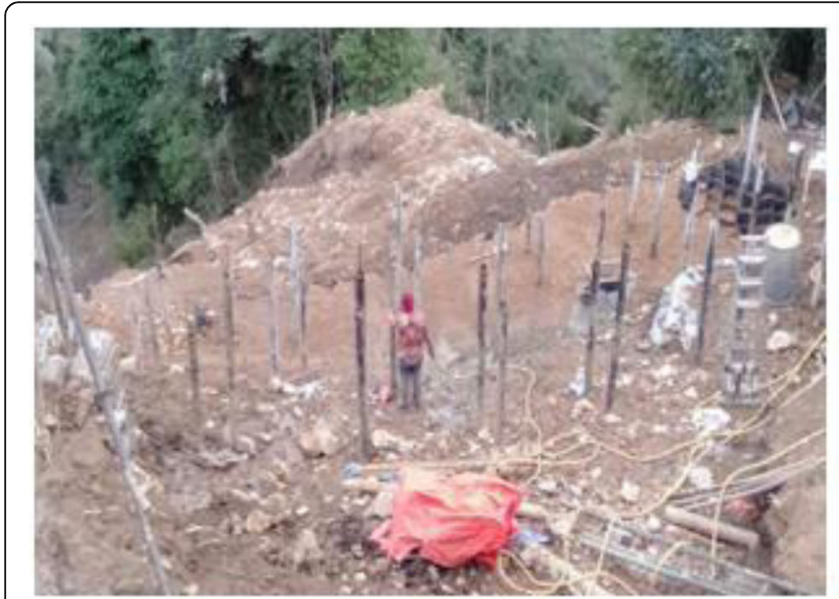

(a)

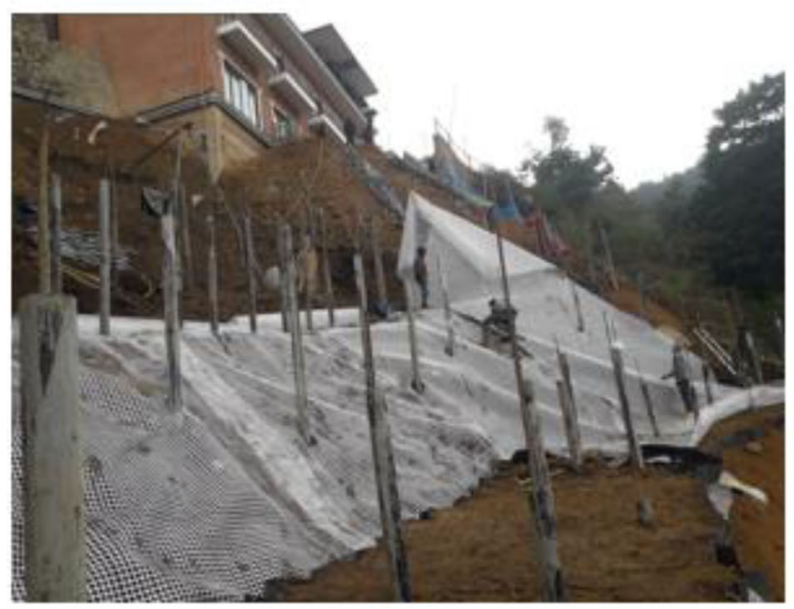

(c)

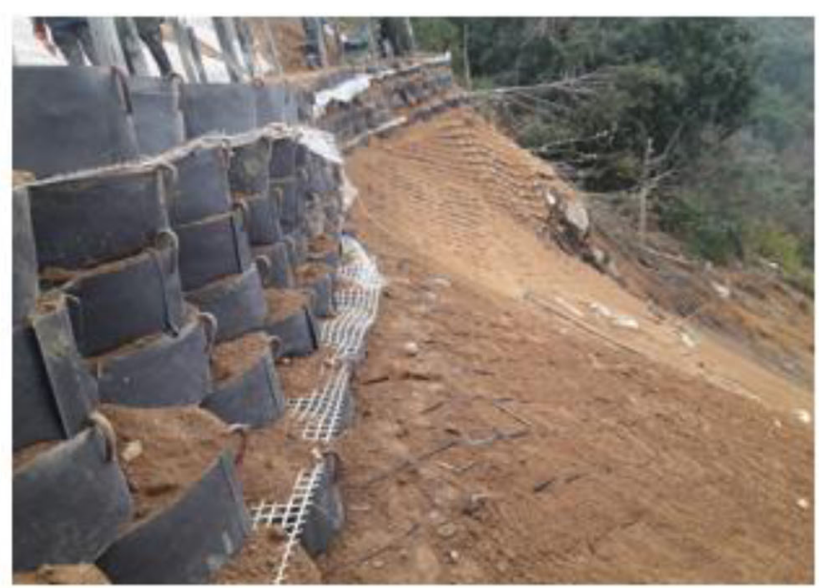

(b)

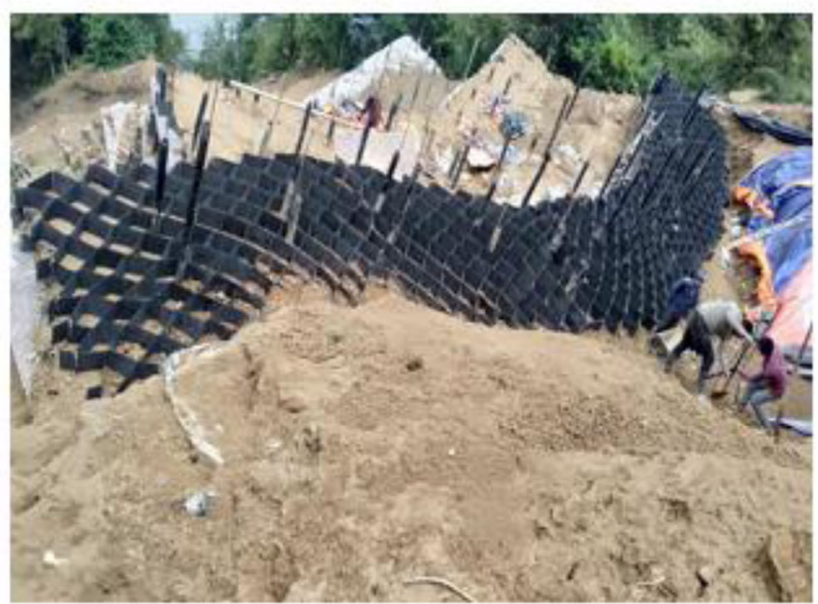

(d)

Fig. 8 a Installation of micropile, $\mathbf{b}$ Geocell wall, $\mathbf{c}$ Laying of geogrid inside the micropile in slope area for stable of back fill materials soil, $\mathbf{d}$ Laying of geocell wall inside micropile 
which enable the technique to be used with any existing FE analysis software (Fig. 7). All the approach requires of a slope analyst is computation of factored Mohr Coulomb strength parameters.

The simplified Bishop method (Bishop, 1955) has been widely used in slope stability analysis and is regarded as the best method of limit equilibrium for calculating the factors of safety of circular slip surfaces. In this method, the inter slice forces are assumed to be horizontal, or the vertical inter slice forces are neglected, the vertical force equilibrium and the moment equilibrium about the center of the circular slip surfaces are satisfied, but the horizontal force equilibrium is not considered.

The simplified analysis is as follows:

$$
\tau=\frac{1}{F}\left(c^{\prime}+\sigma^{\prime} \tan \phi^{\prime}\right)
$$

To find $\sigma^{\prime}$ resolve forces in the vertical direction to obtain

$$
\begin{aligned}
& W-\frac{1}{F}\left(c^{\prime}+\sigma^{\prime} \tan \phi^{\prime}\right) \Delta X \tan \alpha-\left(\sigma^{\prime}+u\right) \Delta X=0 \\
& \therefore \sigma^{\prime}=\frac{W-u \Delta X-\frac{1}{F} c^{\prime} \Delta X \tan \alpha}{\Delta X\left(1+\left(\tan \phi^{\prime} \tan \alpha\right) / F\right)}
\end{aligned}
$$

Now $\mathrm{F}=$ sum (maximum resisting forces around $\operatorname{arc}$ )/ sum(moving forces around arc)

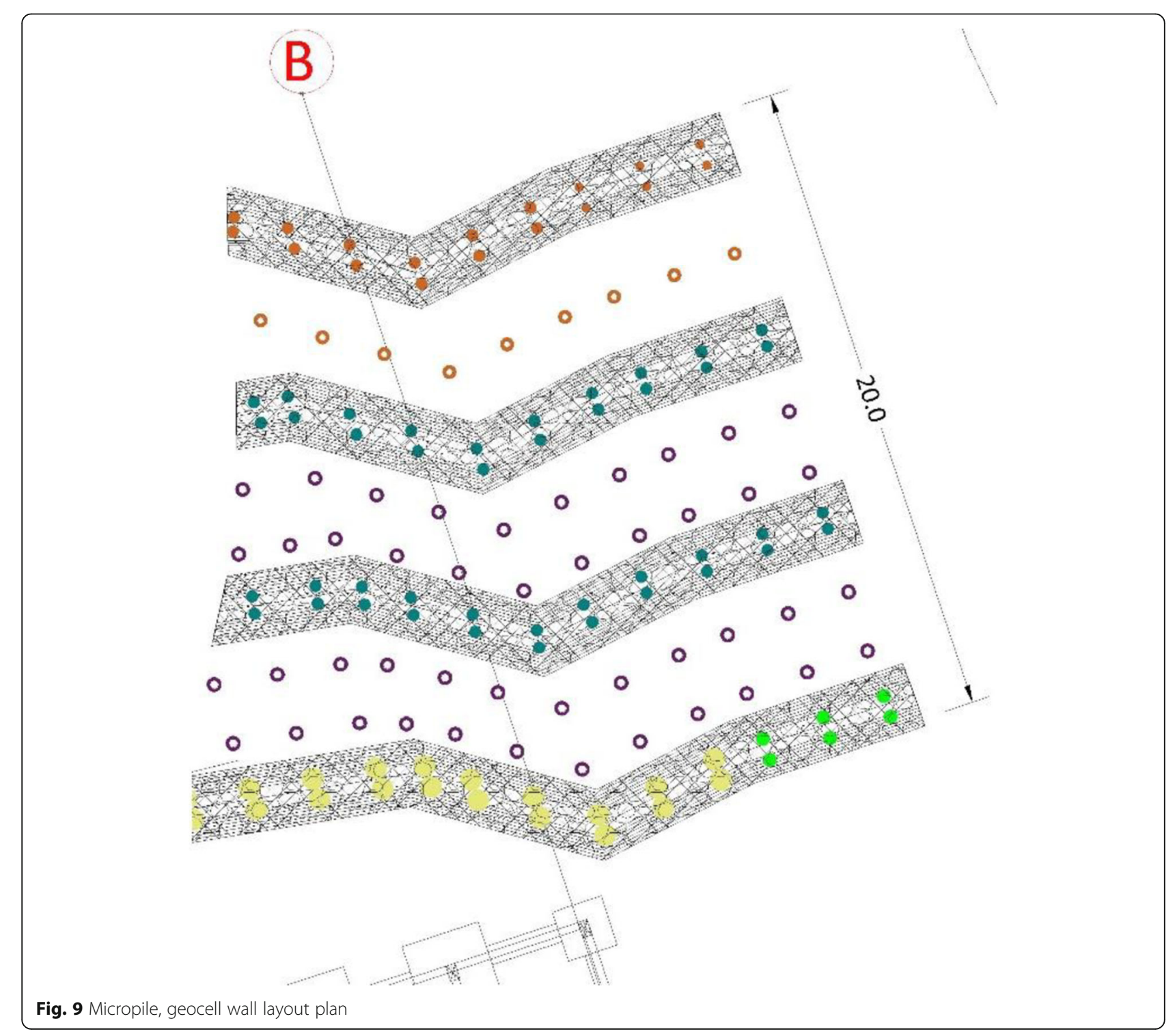




$$
\begin{aligned}
& =\frac{\sum\left(c^{\prime}+\sigma^{\prime} \tan \phi^{\prime}\right) \Delta X \sec \alpha}{\sum W \sin \alpha} \\
& =\frac{\sum\left\{\left[c^{\prime} \Delta X+(W-u \Delta X) \tan \phi^{\prime}\right] \frac{1}{M_{\alpha}}\right\}}{\sum W \sin \alpha}
\end{aligned}
$$

Where, $M_{\alpha}=\cos \alpha+\frac{\sin \alpha \tan \phi^{\prime}}{F}$

$\tau=$ shear strength

$\sigma=$ normal stress

$\phi=$ angle of friction

$W=$ Weight of slice

$\Delta X=$ width of slice

$u=$ pore pressure

To facilitate the analyses of slope stability for a large number of potential failure surfaces and a variety of conditions, computer programs are used. The Bishop Method yields factors of safety that are higher than those obtained with an ordinary method of slices. Furthermore, the two methods do not lead to the same critical circle. It has also been found that the disagreement increases as the central angle of a critical circle increases. Analysis by a more refined methods involving consideration of the forces acting on the sides of slices shows that the simplified Bishop Method yields answers to factors of safety that are close to the correct answer.

We have numerically modelled the project site using FEM in the static condition considering it as a continuum by SSR approach. By determining the factor of safety of failed slope, post disaster analysis is carried out. While, by using FEM methodology, stress developed in the slope is determined to focus on probable failure. The analysis was performed using Phase2 software. FEM, a widely accepted method of numerical modelling of slopes works on the principle of discretization of whole design into a fixed number of elements through which continuous variation in material properties takes place. A 2D, three nodded triangular plane strain elements have been used to discretize the slope design. The SSR approach with non-failure criteria has been adopted. Since the maximum shear strain of the failure zone coincides with the rupture surface, it is thus assumed that failure mechanism of slope is directly related to the development of shear strain.

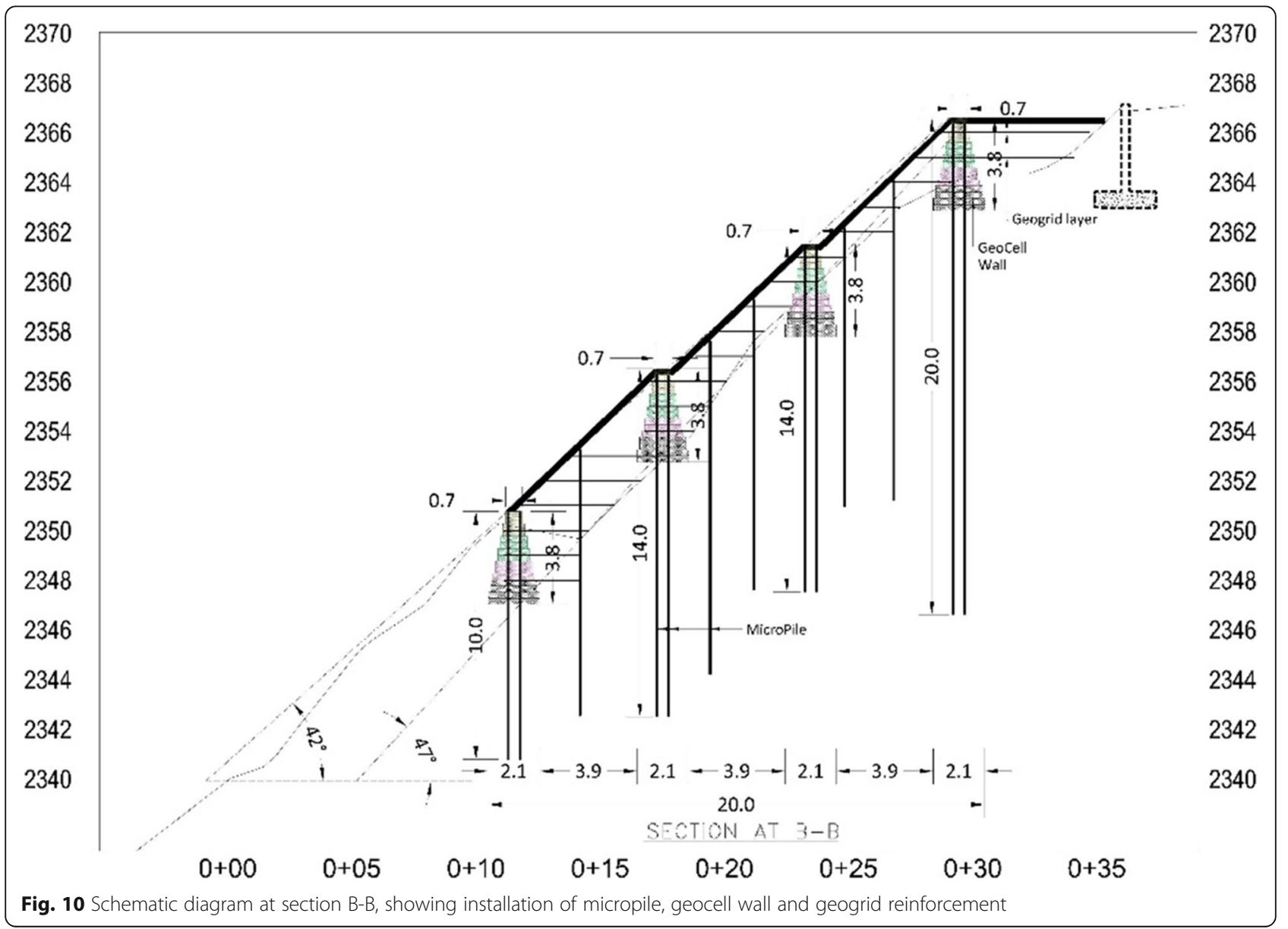




\section{Sequence of construction method}

The construction methods with reinforce soil using geogrid are well explained by Simac (1990). Similarly, Dash et al. (2007) have explained how geocell acts as a rigid mattress and can distribute the applied load to a larger surface area. Further, Zhang et al. (2010) explained how geocell can reduce the settlement and increase the load carrying capacity. (Bush et al. 1990) explained about the construction of geocell and its installation in the field. Elarabi and Soorkty (2014) has explained about micropiles and suitable drilling techniques for the reinforcement with the micropile.

In this research also, like execution of any other civil engineering work, at first the site was cleared, excessive debris of the failed slope was removed and the path was constructed for the commencement of slope protection work. The protection method made use of driven micropiles with the combination of geocell and geogrid as shown in (Fig. 8). The slope protection work commenced from the toe of the slope and micropiles were driven of varying depth on the ground (Fig. 9). In total 139 micropiles with different lengths from $10 \mathrm{~m}$ to $20 \mathrm{~m}$, $2 \mathrm{~m} \mathrm{c} / \mathrm{c}$ distance were driven throughout the length of the slope as shown in Fig. 10. As seen in section, total of four geocells were constructed with base of the geocell wall of $2.1 \mathrm{~m}$ wide, which tapered to $0.7 \mathrm{~m}$ at the top, the total height of each geocell wall was $3.8 \mathrm{~m}$. The geocells were anchored to the ground using a J hook of $20 \mathrm{~mm}$ dia at $0.5 \mathrm{~m} \mathrm{c} / \mathrm{c}$ on both edges. Prior to execution of later geocell wall, the slope between the prior and the later geocell wall was maintained by filling with granular materials reinforced using geogrid at an interval of $1 \mathrm{~m}$ vertical spacing. After the completion of micropiles, the geocell wall and slope maintenance reinforced with geogrid and a layer of geocell were laid throughout the slope along its length which was anchored with $20 \mathrm{~mm}$ dia J hook @ $0.75 \mathrm{~m} \mathrm{c} / \mathrm{c}$ both ways. Later, bioengineering (use of vegetation) was done along the slope.

\section{Analysis and result}

The slope was evaluated for a factor of safety as mentioned in earlier sections. Figure 11 illustrates that the factor of safety of the existing slope before failure was found to be 0.86 that was analyzed as per Shear Strength Reduction (SSR) method. The factor of safety of 0.882 for existing slope before failure analyzed as per Bishop's method was also noticed during simulation (Fig. 12). Since both SSR and Bishop's method showed factor of safety less than 1, so slope was prone to fail which was seen in the site. To overcome this issue, geocell, micropile and geogrid were applied in the simulations and FoS was evaluated again.

It was found that the factor of safety for the slope was increased from 0.882 to 1.076 form limit equilibrium

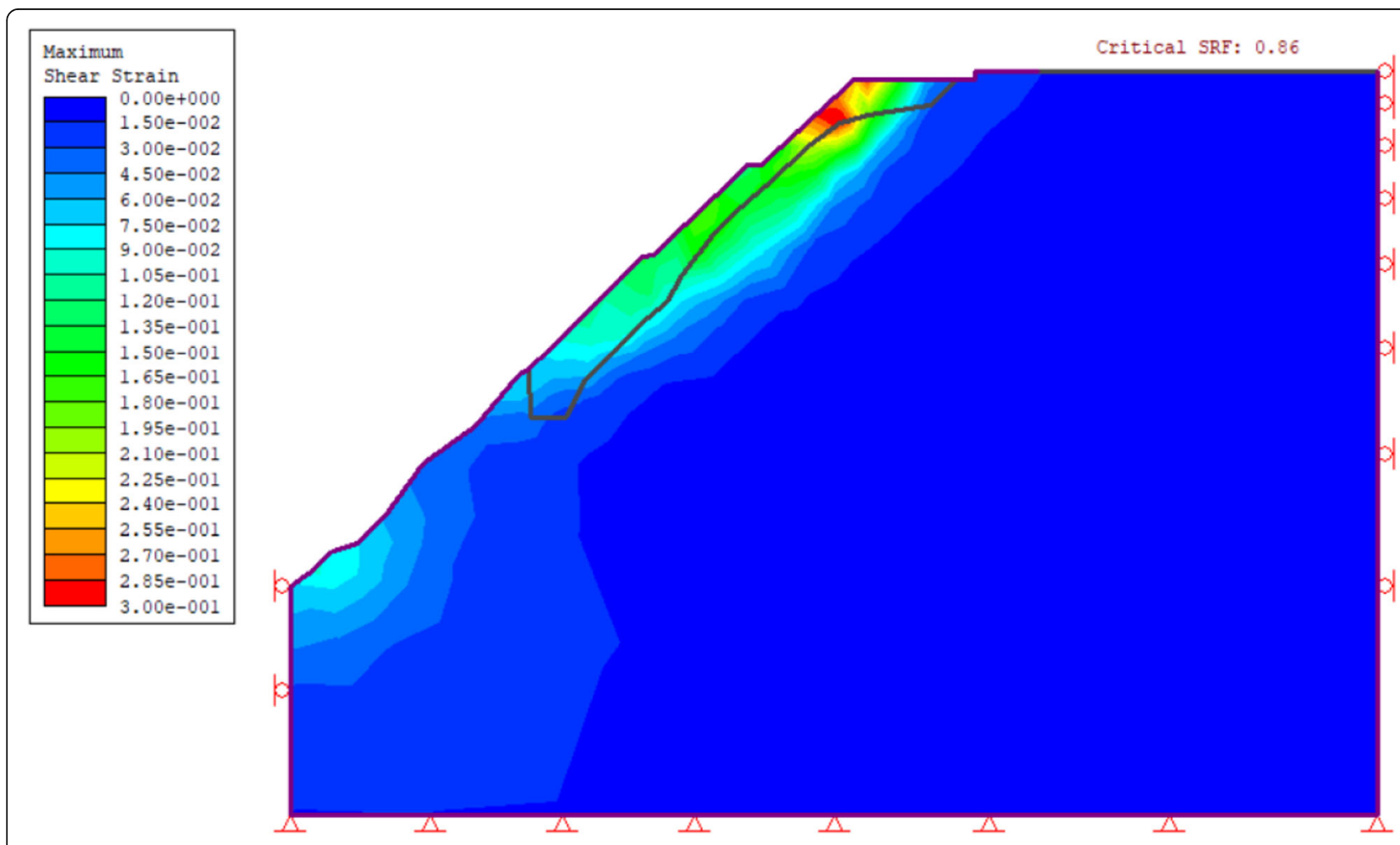

Fig. 11 Maximum shear stress for slope without reinforcement 


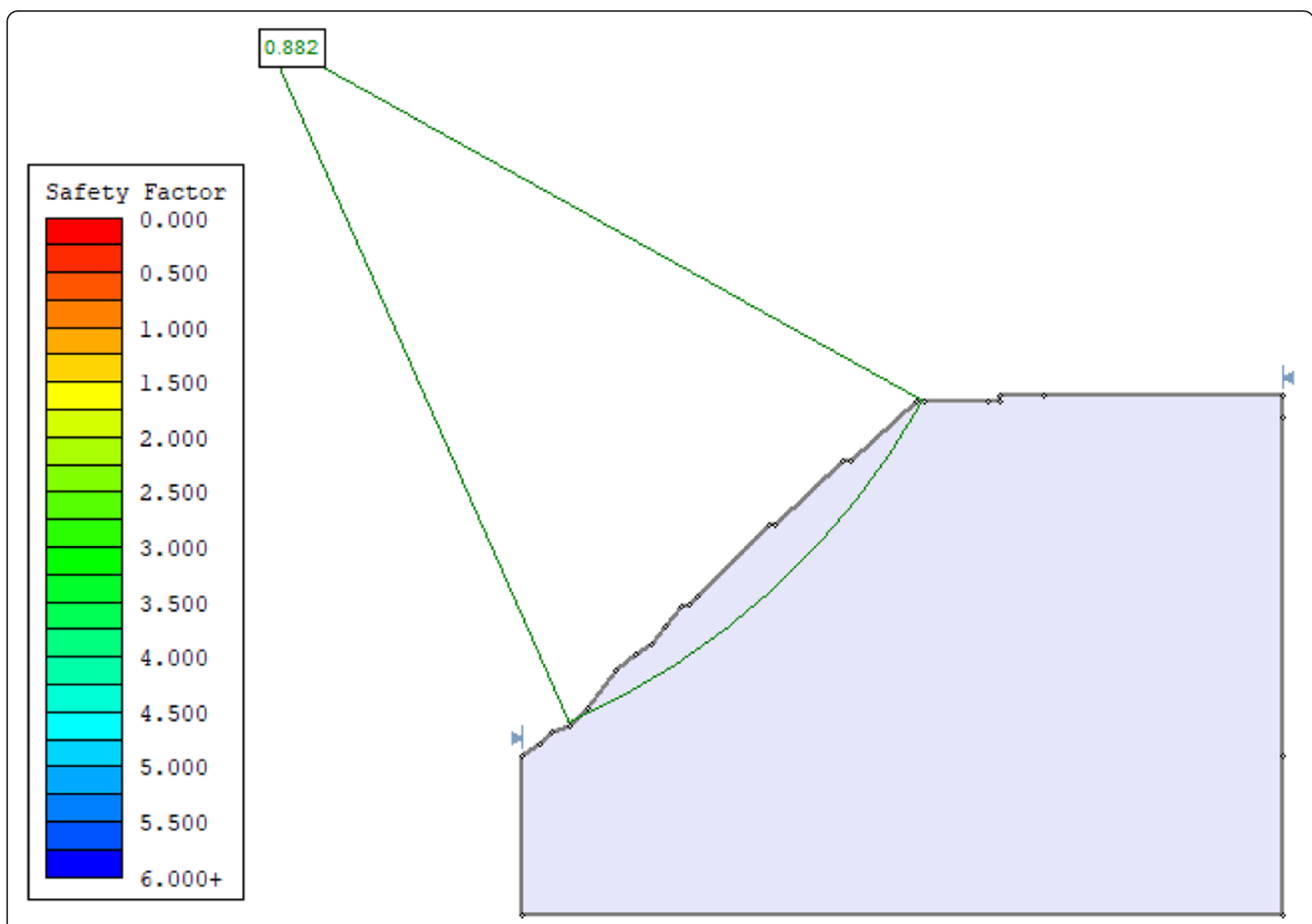

Fig. 12 Slip surface as per Bishops

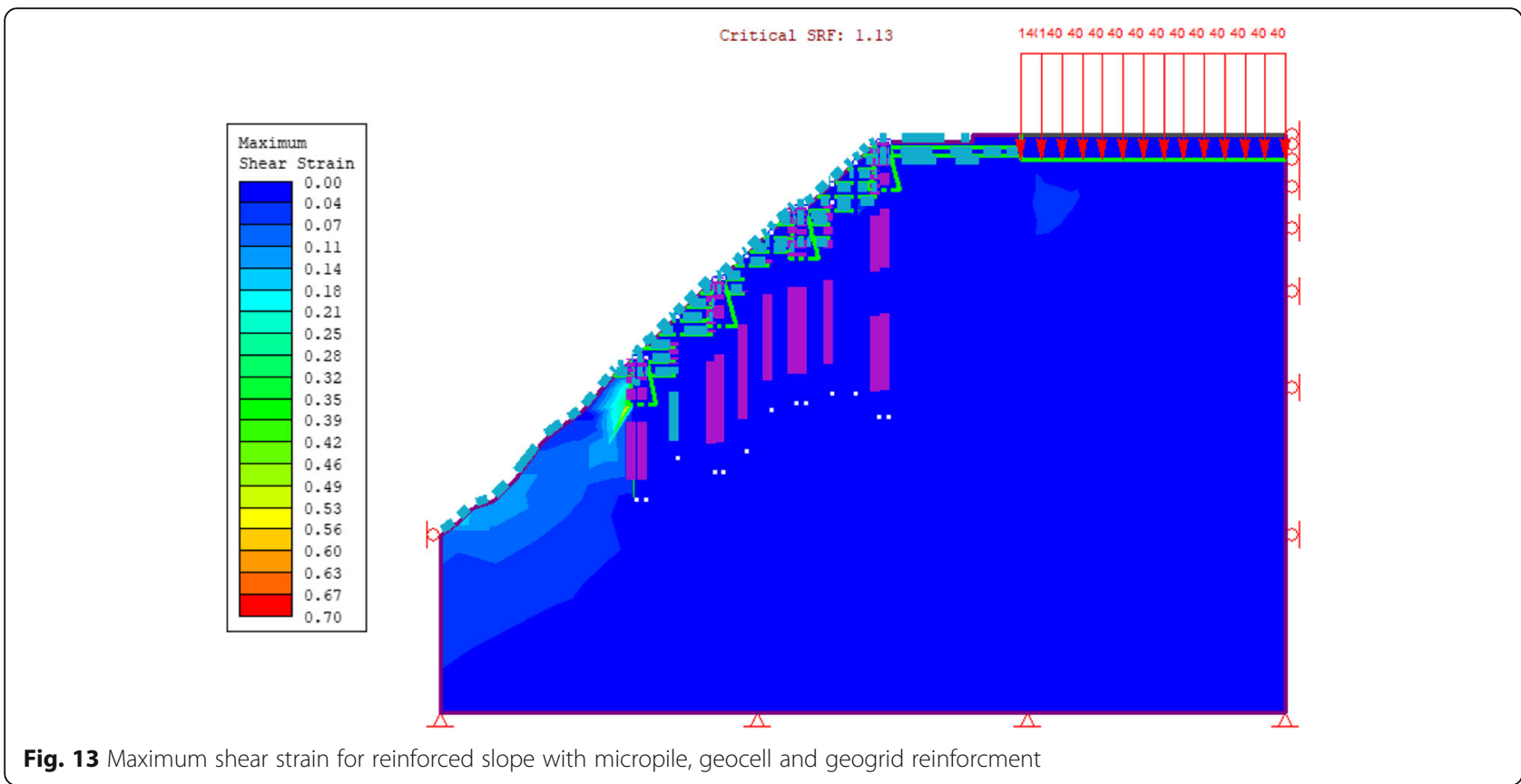

Fig. 13 Maximum shear strain for reinforced slope with micropile, geocell and geogrid reinforcment 


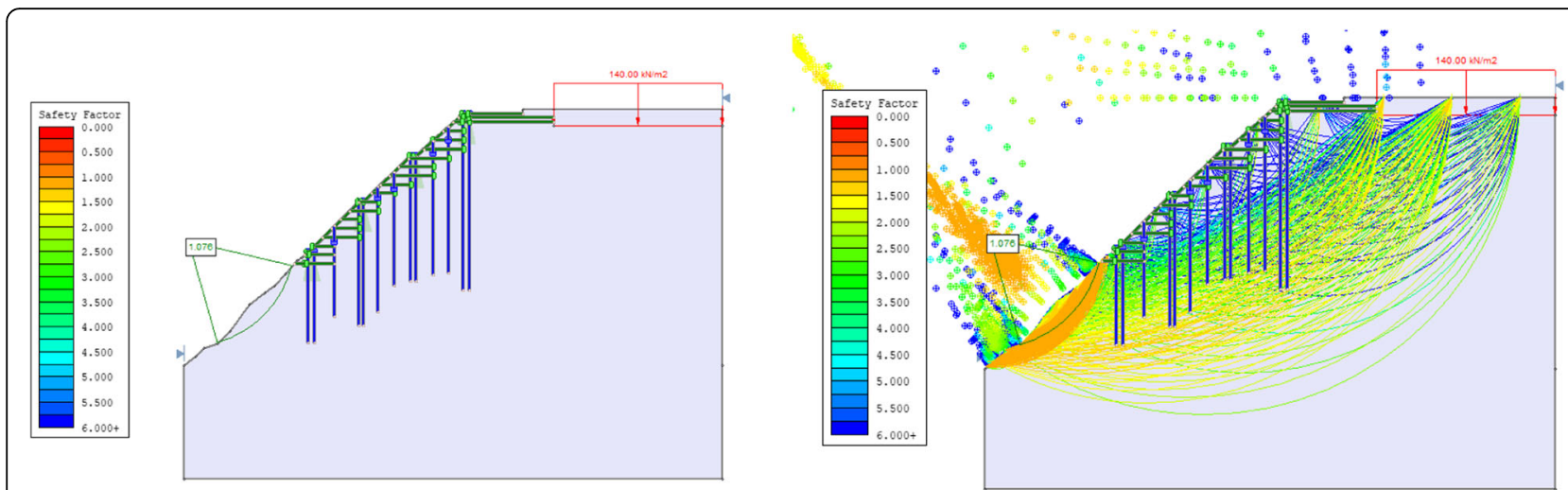

Fig. 14 In left, slip surface as per Bishops for overall fos of reinforced soil with micropile, geocell wall and geogrid, in right, slip surface as per Bishops for factor of safety of individual materials

method. Bishops (1995), suggested that to calculate the factor of safety of slope, the whole slope is divided into vertical slices and each of them is individually analyzed using circular failure analysis to get the individual slice factor of safety and summarized for overall factor of safety of slope.

The factor of safety according to SSR method was found to be 0.86 for the natural unreinforced slope and the factor of safety was 1.13 after reinforcement work with a combination of micropile, geogrid and geocell (Fig. 13). From Fig. 14, it can be observed that the factor of safety according to the Bishops method was found to be 1.076 after the slope was mitigated with the combination of micropile, geocell and geogrid, which was 0.882 for the natural unreinforced slope (Table 2). The factor of safety was in the range of 1 to 4 where the micropiles were driven into the slope.

The failure slope was analyzed being mitigated with the combination of micropile, geocell and geogrid and it was observed that the factor of safety was improved and obtained to be greater than 1 (Fig. 13 and Fig. 14).

The result of the FE analysis were compared to answers obtained from the Bishop limit equilibrium method computed in Slide software, a slope stability program developed by Rocscience. The FE factor of safety result agreed very well with the factor of safety by the limit equilibrium method.

Table 2 Difference of factor of safety by finite element method and limit equilibrium method

\begin{tabular}{lll}
\hline & $\begin{array}{l}\text { FoS of Natural } \\
\text { Slope }\end{array}$ & $\begin{array}{l}\text { FoS of Reinforced } \\
\text { slope }\end{array}$ \\
\hline $\begin{array}{l}\text { Shear reduction Method } \\
\text { (SSR) }\end{array}$ & 0.86 & 1.13 \\
\begin{tabular}{l} 
Bishop Method \\
\hline
\end{tabular} & 0.882 & 1.076 \\
\hline
\end{tabular}

\section{Discussion}

There are many methods for the stability analysis of slope. These are categorized into conventional and numerical methods. For the existing slope before failure it was observed that the factor of safety was less than 1 for Bishops as well as SSR method and the angle of slope was 42 . So, it was prone to failure as observed practically. After the failure of slope the angle of slope was increased to $47^{\circ}$ and stability was more critical. So, the failed slope was mitigated with the introduction of reinforcement combination of micropile, geogrid and geocell. Then it was analysed using Phase-2 for SSR method and Slide for Bishop Method. Both analysis results showed that the factor safety was increased to more than 1 .

There are various methods for slope failure mitigation. In recent years, geosynthetic, geocell, and geogrid combined with micropiles are being used extensively in various slope stabilization works. Micropiles are widely used to stabilize slopes especially for slopes located in steep, hilly, or mountainous areas; as they are simple, fast, economical and environmentally friendly. This research has attempted to validate the least popular but economical solution for the mitigation and control of critical slopes. The study results show that reinforcement of slope using micropile, geogrid and geocell shows better results in slope stabilization work. In which, micropile was used in the analysis to resist the lateral and shear force and act as anchorage as well as the grouting filled up the fissures present in the soil mass. Geocell wall was used to act as a retaining structure at intervals and confine the filled soil material as well as the porous nature of geocell facilitated the seepage of water through the soil without soil loss. Geogrid was used in the backfill of soil in layers to maintain the slope and increase the shear strength of soil. 


\section{Conclusion}

The slope stability analysis is a challenging work in geotechnical engineering. Formerly, the limit equilibrium method of analysis was widely used due to its clear physical meaning and simple calculation. Now, with the development of the finite element method, the strength reduction method is gradually recognized to determine the factor of safety of slope. In this paper, the factor of safety of slope is firstly calculated by Bishop's method, which is then compared with the safety factor obtained from the strength reduction method by FEM. And, from the both limit equilibrium and finite element method, a factor of safety was found greater than 1. After that construction has been done and stabilized.

The following concluding remarks can be drawn by this work.

- The main cause of failure for this slope was water logging, natural slope angle and surcharge load of a building.

- The mitigation measure required a sustainable and economical solution that reinforces the soil as well as allows the flow of seepage water without erosion of soil. For such conditions of slope, the combination of reinforcement of soil with geocell, micropile and geogrid turns out to be the best solution.

- The factor of safety was increased after reinforcement using the combination of micropile, geogrid and geocell.

- Slope stabilization with a combination of reinforcement of soil with geogrid, geocell and micropile is a new technology for Nepal that shows good results to mitigate slope failure issues in the dynamic Himalayan slope.

\section{Acknowledgements}

The authors would like to thank Chandragiri Hills Ltd., for funding and trusting to implement new method of slope stabilization in Nepal, the first of its kind. Authors would like to acknowledge team GS Soil and Materials for testing of sample of project area.

\section{Authors' contributions}

Sanjaya Kumar Jain was involved in the data collection in field, data analysis, simulations and writing the manuscript. And all other author contributed in data analysis, simulations and writing the paper. The author(s) read and approved the final manuscript.

\section{Funding}

Chandragiri Hills Ltd. has funded the project for analysis and construction.

\section{Availability of data and materials}

The most of the data is collected from field work and simulations. Some of the data generated or analyzed during this study are included in the published articles which is mentioned in the paper.

\section{Declarations}

\section{Competing interests}

The authors declare that they have no competing interests.

\section{Author details}

${ }^{1}$ Lincoln University College, Kota Bharu, Malaysia. ${ }^{2}$ ERT Tech Pvt. Ltd, Kathmandu, Nepal. ${ }^{3}$ Tribhuwan University, Pulchowk campus, Kirtipur, Nepal. ${ }^{4}$ Wuhan University of Technology, Wuhan, China.

Received: 13 September 2020 Accepted: 21 April 2021

Published online: 02 May 2021

\section{References}

Ausilio E, Conte E, Dente G (2001) Stability analysis of slopes reinforced with piles. Comput Geotech 28(8):591-611. https://doi.org/10.1016/S0266-352X(01 00013-1

Bathurst RJ, Jarrett PM (1988) Large-scale model tests of geocomposite mattresses over peat subgrades

Bush D, Jenner C, Bassett R (1990) The design and construction of geocell foundation mattresses supporting embankments over soft grounds. Geotext Geomembr 9(1):83-98. https://doi.org/10.1016/0266-1144(90)90006-X

Cancelli A, Rimoldi P, Montanelli F (1993) Index and performance tests for geocells in different applications, in Geosynthetic soil reinforcement testing procedures, edited. ASTM International

Chen R, Chiu Y (2008) Model tests of geocell retaining structures. Geotext Geomembr 26(1):56-70. https://doi.org/10.1016/j.geotexmem.2007.03.001

Dahal RK, Hasegawa S, Nonomura A, Yamanaka M, Dhakal S, Paudyal P (2008) Predictive modelling of rainfall-induced landslide hazard in the lesser Himalaya of Nepal based on weights-of-evidence. Geomorphology 102(3-4): 496-510. https://doi.org/10.1016/j.geomorph.2008.05.041

Dahal RK, Hasegawa S, Yamanaka M, Dhakal S, Bhandary NP, Yatabe R (2009) Comparative analysis of contributing parameters for rainfall-triggered landslides in the lesser Himalaya of Nepal. Environ Geol 58(3):567-586. https://doi.org/10.1007/s00254-008-1531-6

Dash SK, Krishnaswamy N, Rajagopal K (2001) Bearing capacity of strip footings supported on geocell-reinforced sand. Geotext Geomembr 19(4):235-256. https://doi.org/10.1016/S0266-1144(01)00006-1

Dash SK, Rajagopal K, Krishnaswamy N (2007) Behaviour of geocell-reinforced sand beds under strip loading. Can Geotech J 44(7):905-916. https://doi. org/10.1139/t07-035

Dash SK, Sireesh S, Sitharam T (2003) Model studies on circular footing supported on geocell reinforced sand underlain by soft clay. Geotext Geomembr 21(4): 197-219. https://doi.org/10.1016/S0266-1144(03)00017-7

Elarabi H, Soorkty AA (2014) Construction of micropiles using pressure techniques. J Civil Eng Architecture 8(1):74

Hagen, T. (1969), Report on the Geological survey of Nepal, Vol. 1: preliminary reconnaissance, Denkschriften der Schweizerischen Naturforschenden Gesellschaft Memoires de la Societe Helvetique des Sciences Naturelles, 84(1), 185

Krishnaswamy N, Rajagopal K, Latha GM (2000) Model studies on geocell supported embankments constructed over a soft clay foundation. Geotech Test J 23(1):45-54

Lee C, Hull T, Poulos H (1995) Simplified pile-slope stability analysis. Comput Geotech 17(1):1-16. https://doi.org/10.1016/0266-352X(95)91300-S

Li X, Pei X, Gutierrez M, He S (2012) Optimal location of piles in slope stabilization by limit analysis. Acta Geotech 7(3):253-259. https://doi.org/10.1007/s11440012-0170-y

Ling HI, Leshchinsky D, Wang J-P, Mohri Y, Rosen A (2009) Seismic response of geocell retaining walls: experimental studies. J Geotech Geoenviron 135(4): 515-524. https://doi.org/10.1061/(ASCE)1090-0241(2009)135:4(515)

Lizzi F (1982). The pali radice (root piles)" symposium on soil and rock improvement techniques including geotextiles reinforced earth and modem piling Methods Bangkok D3

Madhavi Latha G, Rajagopal K, Krishnaswamy N (2006) Experimental and theoretical investigations on geocell-supported embankments. Int J Geomechanics 6(1):3035. https://doi.org/10.1061/(ASCE)1532-3641(2006)6:1(30)

Mehrjardi GT, Tafreshi SM, Dawson A (2012) Combined use of geocell reinforcement and rubber-soil mixtures to improve performance of buried pipes. Geotext Geomembr 34:116-130. https://doi.org/10.1016/j. geotexmem.2012.05.004

Palmerton J (1984) Stability of moving land masses by cast-in-place piles (R). Federal Highway Administration, Washington DC

Pearlman S, Wolosick J (1992) Pin piles for bridge foundations, paper presented at Proceedings of the 9th Annual International Bridge Conference 
Pokharel SK, Han J, Leshchinsky D, Parsons RL, Halahmi I (2010) Investigation of factors influencing behavior of single geocell-reinforced bases under static loading. Geotext Geomembr 28(6):570-578. https://doi.org/10.1016/j. geotexmem.2010.06.002

Simac M (1990) Design methodology for miragrid reinforced soil retaining walls. Mirafi Inc., Charlotte, p 110

Sireesh S, Sitharam T, Dash SK (2009) Bearing capacity of circular footing on geocell-sand mattress overlying clay bed with void. Geotext Geomembr 27(2):89-98. https://doi.org/10.1016/j.geotexmem.2008.09.005

Soeters R, Van Westen C (1996) Slope instability recognition, analysis and zonation. Landslides Investigation Mitigation 247:129-177

Stöcklin J, Bhattarai K (1977) Geology of the Kathmandu area and central Mahabharat range. Nepal Department of Mines and Geology, Himalayan Report, Nepal

Sun S-W, Wang W, Zhao F (2014) Three-dimensional stability analysis of a homogeneous slope reinforced with micropiles. Math Probl Eng 2014:1-11. https://doi.org/10.1155/2014/864017

Tafreshi SM, Dawson A (2010) Comparison of bearing capacity of a strip footing on sand with geocell and with planar forms of geotextile reinforcement. Geotext Geomembr 28(1):72-84. https://doi.org/10.1016/j.geotexmem.2009.09.003

Tafreshi SM, Dawson A (2012) A comparison of static and cyclic loading responses of foundations on geocell-reinforced sand. Geotext Geomembr 32: 55-68. https://doi.org/10.1016/j.geotexmem.2011.12.003

Wu, K., and D. Austin (1992), Three-dimensional polyethylene geocells for erosion control and channel linings, in Geosynthetics in filtration, drainage and Erosion control, edited, 275-284, Elsevier

Yadav M, Agnihotri AK, Priyadarshee A, Dhane G (2014) Application of geocells in reinforcement of soil: a review. J Civ Eng Environ Technol 1(5):60-64

Yang X, Han J, Pokharel SK, Manandhar C, Parsons RL, Leshchinsky D, Halahmi I (2012) Accelerated pavement testing of unpaved roads with geocellreinforced sand bases. Geotext Geomembr 32:95-103. https://doi.org/10.101 6/j.geotexmem.2011.10.004

Zhang L, Zhao M, Shi C, Zhao H (2010) Bearing capacity of geocell reinforcement in embankment engineering. Geotext Geomembr 28(5):475-482. https://doi. org/10.1016/j.geotexmem.2009.12.011

Zhou H, Wen X (2008) Model studies on geogrid-or geocell-reinforced sand cushion on soft soil. Geotext Geomembr 26(3):231-238. https://doi.org/10.1 016/j.geotexmem.2007.10.002

\section{Publisher's Note}

Springer Nature remains neutral with regard to jurisdictional claims in published maps and institutional affiliations.

\section{Submit your manuscript to a SpringerOpen ${ }^{\circ}$ journal and benefit from:}

- Convenient online submission

- Rigorous peer review

- Open access: articles freely available online

- High visibility within the field

- Retaining the copyright to your article

Submit your next manuscript at $\boldsymbol{\nabla}$ springeropen.com 